DOI: $10.4274 /$ tftr.56.75

\title{
Electrodiagnosis in Lumbar Spinal Stenosis: A Review
}

\section{Lomber Spinal Stenozda Elektrodiagnoz: Bir Derleme}

\author{
Stephen KISHNER ${ }^{1}$, Osman Hakan GÜNDÜZ ${ }^{1,2}$, Satvik MUNSHI ${ }^{1}$, Shalinder GUPTA ${ }^{3}$, Nicholas GOYENECHE ${ }^{1}$ \\ ${ }^{1}$ Louisiana State University Health Sciences Center, Section of Physical Medicine and Rehabilitation, New Orleans, Louisiana, USA \\ ${ }^{2}$ Marmara University School of Medicine, Department of Physical Medicine and Rehabilitation, Istanbul, Turkey \\ ${ }^{3}$ Louisiana State University Health Sciences Center, Shreveport, Louisiana, USA
}

\section{Summary}

Lumbar spinal stenosis (LSS) is a narrowing of the spinal canal and/or the neuroforamina through which the spinal cord roots enter and exit. The symptoms of LSS usually begin over the course of several months and include neurogenic claudication. This is characterized by low back pain that radiates down one or both legs producing pain or weakness. LSS can be quite debilitating and can have a profound negative effect on one's activities of daily living and overall quality of life. Imaging studies, such as computed tomography (CT) and magnetic resonance imaging (MRI) are routinely performed in the work-up of suspected LSS. In recent years, there has been much controversy over the actual clinical usefulness of these studies. When compared to electrodiagnostic studies, CT and MRI have been shown to have increased false negative and false positive rates. Electrodiagnostic studies show dynamic physiological neural function and has become a valuable tool in LSS. This information can be used to determine the location and severity of LSS, differentiate LSS from other conditions, and monitor the progression. Electrodiagnostic techniques such as somatosensory evoked potentials, dermatomal somatosensory evoked potentials (DSEPs), and paraspinal mapping (PM) increase both the sensitivity and specificity in diagnosing LSS. DSEPS provide useful information on multi-level, multiple rootlet disease. PM reflects the physiology of nerve roots and has been found to be superior to extremity needle EMG. Electrodiagnostic techniques are becoming the standard in the diagnosis and therapeutic decisions for LSS and other related diseases. Turk J Phys Med Rehab 2010;56:75-80.

Key Words: Lumbar spinal stenosis, electrodiagnosis, low back pain, lumbar radiculopathy, paraspinal mapping

\section{Özet}

Spinal kanalda ya da sinir köklerinin gectiği nöral foramenlerde daralma lomber spinal stenoz (LSS) olarak adlandırılır. LSS yaşam kalitesini belirgin derecede etkileyip engelliliğe neden olabilir. LSS'nin belirtileri aylar içinde ortaya çıkar. Nörojenik klodikasyon, tek ya da her iki alt ekstremiteye yayılan bel ağrısı ve güçsüzlük LSS'nin semptomları arasında sayılabilir. LSS düsünülen olgularda bilgisayarlı tomografi (BT) ve manyetik rezonans görüntüleme (MRG) gibi yöntemler rutin olarak kulIanılmaktadır. Fakat bu tetkiklerin LSS tanııına katkısı ile ilgili tartışmalar giderek artmaktadır. Elektrodiagnostik çalıșmalarla karsılaștırıldığında BT ve MRG'nin yalancı negatif ve yalancı pozitiflikleri daha fazladır. Nöral fonksiyonların gerçek zamanlı durumunu ortaya koyan elektrodiagnostik incelemeler LSS'de oldukça yararlıdır. Elektrodiagnoz ayIıca, LSS'nin lokalizasyonu ve siddeti konusunda bilgi verir; hastalığın ayırıcı tanısında ve progresyonunun takibinde de yararlıdır. Somatosensoriyel uyandırılmış potansiyeller, dermatomal somatosensoriyel uyandırılmış potansiyeller (DSEP) ve paraspinal haritalama (PH) gibi elektrodiagnostik teknikler LSS tanısında duyarlılık ve özgüllüğü arttırmaktadır. DSEP, birden fazla kökü ilgilendiren durumlarda yararlıdır. PH ise sinir köklerinin fizyolojik durumunu yansıtır ve ekstremite iğne EMG'sine üstün olduğu gösterilmiştir. Günümüzde elektrodiagnostik incelemeler LSS'nin ve iliş̧ili durumların tanısında ve tedavi seçeneklerinin belirlenmesinde standart inceleme yöntemleri haline gelmektedir. Türk Fiz Tip Rehab Derg 2010;56:75-80.

Anahtar Kelimeler: Lomber spinal stenoz, elektrodiagnoz, bel ağrısı, lomber radikülopati, paraspinal haritalama

\section{Introduction}

Lumbar spinal stenosis (LSS) is defined by a narrowing of the spinal canal and/or the neuroforamina through which the spinal cord roots enter and exit. This anatomical phenomenon can be due to congenital or acquired conditions, and may or may not present with clinical symptoms. Typically the signs and symptoms of LSS begin as the spinal nerve roots, or the cauda equina itself, become impinged upon by the surrounding bony and ligamentous tissues (1). Most commonly, it is the degenerative

Address for Correspondence/Yazışma Adresi: Dr. Stephen Kishner, Louisiana State University Health Sciences Center, Department of Internal Medicine, Section of Physical Medicine and Rehabilitation 1401 Foucher Street, Suite 10012, New Orleans, LA 70115, USA Phone: +1-504-8978948 E-mail: skishn@|suhsc.edu Received/Geliş Tarihi: May/Mayıs 2010 Accepted/Kabul Tarihi: June/Haziran 2010 ๑) Turkish Journal of Physical Medicine and Rehabilitation, Published by Galenos Publishing. / @ Türkiye Fiziksel Tip ve Rehabilitasyon Dergisi, Galenos Yayınevi tarafından basılmıștr. 
form of LSS that results from facet joint capsule hypertrophy, disc degeneration, osteophyte formation, or buckling of the ligamentum flavum (2-4). These pathologic anatomical conditions may act singularly or as a group to produce the syndrome. Conditions, such as spondylolisthesis, spondylosis, or scoliosis can also predispose a person to LSS by chronically altering the mechanical forces placed upon the vertebral discs, joints, and ligaments (5). It should also be noted that LSS could be a sequelae of endocrine, rheumatologic, neoplastic, or idiopathic processes. This review article will focus on the emergence of various electrodiagnostic techniques that may aid in the diagnosis and treatment of LSS.

\section{Prevalence}

It is estimated that nearly 5 of every 1,000 Americans over the age of 50 have some degree of LSS (6). This condition can be quite debilitating when symptomatic, and can have a profound negative effect on one's activities of daily living and overall quality of life. As the population ages, clinicians will likely diagnose this condition more frequently. With the average lifespan increasing, more and more individuals are seeking the preservation of their mobility and flexibility into their later years (7). LSS contributes to an estimated cost of $\$ 100$ billion annually in the United States due to health care costs and lost worker productivity (8). Subsequently, a large amount of research has been conducted over recent years to identify both sensitive and specific diagnostic tools as well as effective treatment measures. Already LSS is the most common indication for lumbar surgery in the United States for persons over the age of 65 (9).

\section{Pathophysiology}

The symptoms of LSS typically begin insidiously over the course of several months. The most common and specific symptom of LSS is neurogenic claudication, or pseudoclaudication (10). This is characterized by low back pain that radiates down one or both legs producing pain or weakness and is precipitated by standing, walking, or lumbar extension, and lessened by a change in position or lumbar flexion. Consequently, patients with neurogenic claudication are significantly limited in their ability to ambulate (11). This pattern is a direct result of the fact that extension narrows the spinal canal, while flexion widens it (12). Other common symptoms include ataxia, weak or "heavy feeling" in the legs, low back pain, and paresthesia and hypoesthesia in the legs. Compounding the diagnosis of LSS is the fact that classic neurogenic claudication may not always be present in patients with LSS. Furthermore, variations of the presenting symptoms can mimic many other conditions, or in fact be superimposed upon other current comorbidities. The key clinical determinant remains the regression of symptoms with lumbar flexion, and worsening with extension; a key distinguishing factor from vascular claudication. At the molecular level, a number of different pathophysiological mechanisms have been purported to explain the symptoms of neurogenic claudication. The closed space within stenotic spinal segments will experience higher epidural pressures, and as a result of the actual mechanical pressure, inflammation and fibrosis of the nerves can ensue (13). Wallerian degeneration may occur, but only in cases of severe nerve compression. It has been hypothesized that arterial perfusion deficiency and venous congestion of the vessels surrounding the nerves may be involved (14). In reality, it is likely the combination of the above factors acting together to affect the excitatory state of the spine roots, altering their ability to efficiently and appropriately transmit action potentials.

\section{Imaging}

Since the basis of LSS appears to be an anatomical impingement of the spinal roots, one would expect to visualize this pathology on imaging studies. Imaging studies have, and continue to be routine in the work-up of suspected LSS. However, there has been much controversy in recent years over the actual clinical usefulness of these studies. Radiographic measurements of the spinal canal have been correlated to symptomatic and asymptomatic LSS, but these measurements have not been definitively proven to be clinically valid (15). It is important to note that the traditional radiographic method used to determine the level of stenosis is the anterior to posterior spinal column distance. Depending on the exact measurement, the terms "absolute" or "relative" stenosis is assigned. This method has since given way to the measurement of the transverse area of the dural sac, secondary to the improved soft tissue imaging provided by magnetic resonance imaging (MRI), in contrast to the older myelography. Many older studies citing the utility of imaging studies in the diagnosis of LSS were reviewed in a meta-analysis by Kent et al. (16). All 14 studies were given research quality ratings of $C$ or lower, indicating weak diagnostic accuracy (16). A significant finding supported by many recent studies has been the high percentage of positive radiographic findings of spinal stenosis in asymptomatic individuals $(17,18)$. In a study by Boden and colleagues (17), $20 \%$ of asymptomatic patients over the age of 60 had imaging studies that were positive for LSS. Further studies have sought to examine the clinical relevance of imaging in LSS. The results have, more often than not, failed to show a correlation between clinical symptoms and spinal canal narrowing in LSS.

A study by Moon et al. (19) had symptomatic LSS patients walk on a treadmill and measured the time to the onset of symptoms and the total ambulation time. They concluded that there was no correlation between these measures and each patient's radiologic parameters (19). In a similar study by Barz et al. (20), the distance walked on the treadmill did predict the degree of stenosis on the MRI, but the diagnostic importance for the severity of clinical symptoms was limited. Another study examined the correlation of the degree of radiographic constriction of the lumbar spinal canal and the patient's perceived level of disability. Using the Oswestry Disability Index (ODI), they found no significant correlation between the ODI percentage scores and central or lateral radiological stenosis (21). To the contrary, one study did find a correlation between spinal canal cross-sectional area and clinical symptoms; however, this was in preoperative patients with severe LSS (22). With most studies failing to show a correlation however, this study appears to be an exception. Therefore, an MRI, by itself, should not be used to determine if lumbar stenosis is the cause of the patient's pain, what their prognosis is for future pain and functionality, nor make definitive decisions on the course of treatment. 


\section{Electrodiagnosis in LSS}

As discussed earlier, the pathologic basis of LSS is compression of nervous tissue, and/or its surrounding vascular components. These compressive insults typically cause the nerves to function abnormally, making electrodiagnostic studies very useful in the investigation of suspected LSS. In contrast to the static anatomic image of an MRI or computed tomography (CT), dynamic physiological function can be obtained from electrodiagnostic studies. This information can be used to determine the location and severity of LSS, differentiate LSS from other conditions, and monitor the progression of the condition. Clinicians have been using nerve conduction studies (NCS) and electromyography (EMG) in the diagnosis of LSS since the 1940's (23). However, only recently have high quality, evidence-based medicine studies began to emerge. The current body of literature in this area, as well as newer electrodiagnostic techniques such as somatosensory evoked potentials (SEPs), dermatomal somatosensory evoked potentials (DSEPS), and paraspinal mapping (PM), will be reviewed.

\section{Nerve Conduction Studies including Late Response Nerve Conduction Studies}

While NCS are typically normal in most cases of LSS, motor and sensory conduction studies can still be a valuable tool in LSS. Prolonged nerve compression is typically required to produce abnormalities of these studies. Therefore, they are usually only abnormal in cases of severe LSS. NCS can be useful in excluding other conditions from the differential diagnosis that can be superimposed upon or similar to LSS. Due to the proximal location of the pathology in LSS, late response NCS, such as F-waves and H-reflexes, have been utilized for many years in the evaluation of radiculopathies (24-27). F-waves, however, have low sensitivity, and are frequently normal, even in clear clinical radiculopathies $(28,29)$. Due to the nature of the intermittent neurogenic claudication in LSS, the effects of lumbar spine position, ambulation, and exercise on various F-wave parameters have been studied for a number of years. The two F-wave parameters, in particular those seem to be affected the most by dynamic testing, are the minimal F-wave distal latency and chronodispersion. In a study by Tang et al. (30), standing for $3 \mathrm{~min}$ produced increased F-wave chronodispersion in LSS and root compression syndromes, but had less effect on the more commonly measured $F$ minimal latency. Furthermore, patients with simple low back pain did not show any F-wave parameter changes after these postural maneuvers (30). London and England measured serial F-waves both before and after ambulation in two patients with neurogenic claudication (31). In both patients, dynamic changes in F-wave parameters were noted post-exercise. These changes consisted of unelicitability or increased latencies, which reversed over the course of 15 minutes following ambulation (31). Adamova et al. (32) used an exercise treadmill test (ETT) as a dynamic variable in patients with LSS diagnosed by CT, diabetic polyneuropathy patients, and a group of healthy control patients. They measured the soleus H-reflex, tibial F-wave, and motor evoked potentials to the abductor hallucis muscle, both before and after the ETT. Only the minimal latency of the tibial F-wave and the latency of the soleus $\mathrm{H}$-reflex exhibited changes after walk loading in patients with LSS (32). In a similar study by Adamova et al. (33), increased chronodispersion of the tibial
F-wave distinguished LSS patients from polyneuropathy patients and healthy controls. Wallbom et al. (34) published a cohort study of neurogenic claudication positive LSS patients, in which all of the subjects underwent physical therapy with half performing additional interval-walking exercises. Changes in F-wave indices - minimal latency, chronodispersion, and persistence - were calculated. The treatment group demonstrated a worsening of F-wave persistence at 8-week follow-up (34). This result highlights the need for more research into conservative treatment modalities for LSS, but it is in-line with the pathophysiologic nature of this condition. The H-wave, or $\mathrm{H}$-reflex, which is predominantly used to test the S1 nerve roots, has also shown utility in LSS diagnostics. The H-reflex measures sensory as well as motor nerve function. Since sensory complaints are more common than motor complaints in patients with radiculopathies, the H-reflex can often be the first abnormality in earlier stages of spinal stenosis (35). There are some definite limitations of $\mathrm{H}$-reflex testing that should be noted. The H-reflex is only easily obtained for S1 nerve roots, and is commonly unelicitable in elderly patients over 60 $(36,37)$. When used however, H-reflex amplitude asymmetry $(>50 \%)$ and prolonged side-to-side latency (>1.0-1.8 msec) seem to be the most useful parameters in detecting nerve root lesions $(24,29,36,38,39)$.

\section{Needle EMG}

Compression of the cauda equina due to a stenotic spinal canal often results in polyradicular insults. Needle electromyography was the first electrodiagnostic technique used in detecting radiculopathy, and still maintains a very high diagnostic yield $(28,40)$. In fact, one study found EMG to have a sensitivity of $72 \%$ and a specificity of $85 \%$ in neurologically abnormal patients (41). Further research has shown abnormal EMGs in $35 \%$ to $64 \%$ of patients with radicular leg pain, and in $51 \%$ to $86 \%$ of those with abnormal neurologic examinations (42). The most common pattern of EMG findings in LSS appears to be multiple, bilateral lumbosacral radiculopathies, occurring with the following frequencies: L5 (48\%), S1 (30\%), L4 (17\%), L3 $(5 \%)$, S2 (4\%), and L2 (3\%) (43). Wilbourn and Aminoff reported that this pattern has been present in approximately $50 \%$ of their LSS patients (44). This pattern was also exhibited in a study by Petropoulos, who performed surgery on 76 LSS patients, of which, $78 \%$ had bilateral, asymmetric radicular findings on EMG exam following a stress test (45). LSS may also present with symmetric or asymmetric bilateral single root lesions, unilateral lesions, fibrillation potentials in a single muscle, or normal studies all together (44). In addition to the possibility of false negatives, false positives can occur secondary to idiopathic polyphasic potentials in $12 \%$ to $35 \%$ of the normal population, morphology changes due to movement of the active recording electrode, prior lumbosacral surgery, or end-plate activity (46-50). Wilbourn and Aminoff reported that EMG findings in LSS most commonly resemble a chronic, but ongoing radiculopathy, evidenced by chronic motor unit action potential (MUAP) changes and fibrillation potentials restricted to distal myotomes (44). Fibrillation potential amplitude has shown a correlation to the approximate age of the lesion, with older lesions exhibiting smaller amplitudes compared to acute insults. Kraft also showed that the fibrillation potential size correlates with the degree of Type I muscle fiber atrophy (51). Analyzing the MUAPs can also be used to gauge the duration 
and progression of LSS. Decreasing recruitment will tend to appear within the first month, followed by polyphasic potentials at 10 weeks, and long-duration, high-amplitude units appear after 2 months (52).

\section{Somatosensory Evoked Potentials}

SEPs monitor nerve impulses and evaluate many aspects of peripheral nerve function. The results from these tests can indicate deficit in mixed peripheral nerves, nerve roots, and in the spinal cord and brain (53). A study done by Kraft et al. (54) suggests that since SEPs are generated from peripheral nerves, it is difficult to make single root conclusions from the data. SEPs can be useful for the overall investigation of nerve root and rootlet dysfunction (55). SEPs more suited for low-grade, chronic compression seen in LSS (54) rather than for acute radiculopathies. SEPs provide a good overall picture of the status of multi-level nerve function (56). Typically, SEPs are normal in the early stages of LSS when symptoms first begin. Electrophysiologic changes usually occur once the condition progresses to conduction block, axon loss, and demyelination of peripheral nerves (41). SEPs are dorsal column dependent and monitor sensory nerve function (54). Because of this, quantitative measurement of motor nerve function often remains normal because of the lack of measurement in the anterolateral column (29). Many different studies have been conducted to support the use of SEPs as an adjunct to imaging in diagnosing and treating LSS. A study done by Keim et al. (53) showed that SEPs are important in establishing the level, extent, and laterality of nerve root compression. A prospective study of 20 patients found that $11 / 20$ patients had intraoperative SEPs that correlated with their CT scan or myelography findings. Findings showed high levels of L4-L5 and S1 involvement that was also supported by Grana et al. (43). The findings also revealed a high level of involvement of the posterior tibial and peroneal nerves SEPs responses at $95 \%$ and $90 \%$, respectively. There were $7 / 20$ patients that had bilateral findings, while only $2 / 7$ reported having bilateral symptoms that supports SEPs having a higher sensitivity in detecting spinal root compression secondary to spinal stenosis. Keim et al. (53) further support this by demonstrating a correlation between improvement in SEP amplitude and clinical symptoms. However, Spielholz et al. (57) showed SEPs were not related to clinical outcome. Brown et al. (58) studied 300 neurosurgical patients and also concluded that no clinical significance could be shown. Kondo et al. (59) demonstrated SEPs to also be effective in monitoring neurogenic claudication secondary to stenosis. The study shows 31/37 patients with abnormal SEPs after stress produced by walking. After surgical procedure, $7 / 9$ of the patients had SEP values which returned to normal demonstrating that SEPS are a safe way to both diagnose LSS and help differentiate between neurogenic and vascular claudication. The possible etiologies of the SEP amplitude reductions in this study include temporal dispersion, rise in thresholds, and blockage of impulses. These amplitude reductions improved when pressure was removed from the measured stenosed area. In recent years, many studies have been performed to assess the value of SEPs in determining location of disease, prognostic indicators, and therapeutic options (54). In summary, numerous studies have shown SEPs to be useful adjuncts to imaging in the management of LSS.

\section{Dermatomal Somatosensory Evoked Potentials}

DSEPs provide useful information on multi-level, multiple rootlet disease. Much like SEPS, DSEPs can detect impaired nerve conduction in multiple segments caused by chronic, low-grade compression (54). The ability of DSEPs to quantitatively measure pain in single nerve roots has advanced the diagnosis of LSS and has been compared to the advancements made in diagnosing distal sensory latency prolongation in CTS. While SEPs give an overall picture of mixed peripheral and spinal cord function, DSEPs provides clinicians the ability to monitor single nerve roots (60). Storm et al. (61) suggests that DSEPS allow physicians to diagnose LSS well before symptoms occur, allowing therapeutic intervention in early stages of LSS. These advancements allow for more efficient diagnosis and treatment of LSS and also give a better understanding of patients with neurogenic compromise (54). Because of this, physicians are better able to determine which patients are more suited for surgical intervention (54). DSEPs test specific dermatomes with standardized normal values. As previously mentioned, DSEPs can provide useful information when monitoring of a single root is needed (56). A study by Snowden et al. (62) showed DSEPs to be a helpful adjunct to CT and MRI imaging when diagnosing LSS. Of 155 patients referred for clinical suspicion of LSS, 58 patients met the criteria for LSS. Abnormalities in DSEP were defined as 1) N1 latency absent or $>2.5$ standard deviations (SD), 2) side-to-side latency difference of $>2 \mathrm{SD}, 3$ ) amplitudes $>2 \mathrm{SD}$, and 4) amplitude ratio $>2 \mathrm{SD}$. The study concluded DSEPs to have $78 \%$ efficacy in predicting single root disease with LSS and $93 \%$ for multiple root with LSS (62). Jensen et al. (63) showed MRIs to have false positive rates as high as $36 \%$ for diagnosing LSS in asymptomatic patients, further supporting the use of DSEPs for diagnosis. DSEPs have been widely accepted for use in diagnosing lumbar radiculopathies (58). A study by Tokuhashi et al. (64) evaluated 94 cases to determine whether DSEPs, biothesiometer, or the Semmes-Weinstein esthesiometer had higher sensitivity for detecting lumbar radiculopathies. DSEPs were found to be more sensitive for diagnosis of LSS when compared to the biothesiometer and the Semmes-Weinstein esthesiometer (64). However, DSEPs were found to not be as effective in determining the severity, extent of numbness, or any immediate changes in sensory dysfunction (64). Dvonch et al. (60) conducted a two-part experiment to show how DSEPs provide the advantage of root specific information. Their results show DSEPs to have an accuracy of $85.7 \%$ when compared to myelography and an accuracy rate of $87.5 \%$ when compared to surgery as the standard (60). One can conclude from this that DSEPs can help determine which roots are affected in LSS and possibly which patients will benefit most from surgery. Kraft et al. (54) supports these studies with their own independent investigation that concluded DSEPs to have a higher odds ratio of 1.59 compared to 0.81 for MRIs alone when compared to surgical outcome. Herron et al. (56) concluded DSEPs to be useful intraoperatively in monitoring unilateral and bilateral nerve root compression. The results show $6 / 30$ cases of unilateral decompression with an average of $9 \mathrm{msec}$ improvement in latency on operated side and $3 \mathrm{msec}$ improvement on non-operated side. Bilateral decompression was noted to have an average improvement of $9 \mathrm{msec}$ on both sides. 


\section{Paraspinal Mapping}

$\mathrm{PM}$ is a relatively new technique that can be done with standard EMG equipment. PM is performed by placing needles in the paraspinal muscles in carefully selected different locations. The protocol entails 4 needle insert sites that are $2.5 \mathrm{~cm}$ lateral to midline at all of the levels tested bilaterally. At each insertion site, a $50 \mathrm{~mm}$ monopolar needle is directed at a 45-degree angle toward the midline and is inserted in approximately $5 \mathrm{~mm}$ intervals until it contacts the spinous process. A score is calculated from each individual needle and then all are added to determine a total PM sensitivity score. Haig et al. (65) conducted 50 studies to ultimately show that PM sensitivity scores had higher sensitivity that either peripheral EMG or imaging alone. The study also showed that PM could help combat the high false positive findings on imaging. PM was also shown by Yagci et al. (66) to be superior to limb EMG in the diagnosis of lumbar spinal stenosis. PM showed a correlation of at least $92.8 \%$ in radiculopathy. Tomasella et al. (67) also proved the high sensitivity of PM compared to imaging in diagnosis of radiculopathy. Leionen et al. (68) conducted a LSS study in which paraspinal muscle exercise endurance was tested along with PM. The 25 patients in this study were asked to perform flexion-extension movements while the paraspinal muscles were tested from L3-S1. The study had 18/21 patients with abnormal PM. Thus, most patients with LSS have abnormal PM that could indicate denervation of paraspinal muscles and possible atrophy of the paraspinal muscles. Studies by Haig et al. (69) indicate that lumbar spine PM abnormalities increase with age, and that different normal values should be set for different ages to help determine age specific abnormal values. Haig et al. (69) demonstrated PM scores $>4$ had $100 \%$ specificity and $30 \%$ sensitivity when comparing a group of patents with pain and imaging suggesting LSS with another group of asymptomatic patients. A composite PM and composite limb score increased the sensitivity to $47.8 \%$ and the specificity of $87.5 \%$. Tong et al. (70) tried to establish a standard of reliability between monopolar and concentric needle in PM. The study showed results with a false positive rate $\langle 5 \%$ when counting a PM value $>2$ as abnormal. PM has been shown to be quite effective in diagnosing LSS. When combined with both conventional imaging and lower extremity EMG, PM increases both the sensitivity and specificity in diagnosing LSS (69). PM has also been documented to be useful in high lumbar root lesions (71).

\section{Conclusion}

Lumbar spinal stenosis (LSS) in the past has been primarily diagnosed on a clinical basis with radiologic support. Clinical symptoms sometimes do not appear until late in the disease course and may not correlate with imaging. There have been numerous studies that demonstrate the usefulness of various electrodiagnostic techniques in the diagnosis and treatment of lumbar spinal stenosis. While CTs and MRIs are routinely performed, they have been shown to have increased false negative and false positive rates when compared to electrodiagnostic studies. Electrodiagnostic studies such as SEPS, DSEPS, and PM increase both the sensitivity and specificity in diagnosing LSS. SEPs monitor many aspects of nerve function and the results can indicate a deficit in mixed peripheral nerves, nerve roots, and in the spinal cord and brain
(53). Despite these limitations, many studies have been shown to support SEPs as an adjunct to other electrodiagnostic techniques in diagnosing LSS. DSEPS provide similar information in the diagnosis and treatment of LSS. DSEPs can detect impaired nerve conduction and provide information on single nerve roots (60). A study by Kraft (72) concluded that DSEPs could detect which roots are affected in LSS and which patients will benefit most from surgical decompression. A limitation of DSEPs is that they have not been found to be useful in the diagnosis of acute radiculopathies (72). PM is another useful technique in the diagnosis of LSS. Yagci et al. (66) demonstrated that PM reflects the physiology of nerve roots better than limb EMG and therefore, was more sensitive than limb EMG in the diagnosis of LSS. In conclusion, electrodiagnostic techniques are important, and may become the standard, in the diagnosis and therapeutic decisions for LSS and other related diseases.

\section{References}

1. Rydevik B, Brown MD, Lundborg G. Pathoanatomy and pathophysiology of nerve root compression. Spine 1984;9:7-15. [Abstract]

2. Singh K, Samartzis D, Vaccaro AR, Nassr A, Andersson BJ, Yoon ST, et al. Congenital lumbar spinal stenosis: a prospective, controlmatched, cohort radiographic analysis. Spine J 2005;5:615-22. [Abstract]

3. Dimaio S, Marmor E, Albrecht S, Mohr G. Ligamentum flavum cysts causing incapacitating lumbar spinal stenosis. Can J Neurol Sci 2005;32:237-42. [Abstract]

4. Sairyo K, Biyani A, Goel V, Leaman D, Booth R, Thomas J, et al. Pathomechanism of ligamentum flavum hypertrophy: a multidisciplinary investigation based on clinical, biomechanical, histologic, and biologic assessments. Spine 2005;30:2649-56. [Abstract]

5. Akuthota $V$, Lento $P$, Sowa $G$. Pathogenesis of lumbar spinal stenosis pain: why does an asymptomatic stenotic patient flare? Phys Med Rehabil Clin N Am 2003:14:17-28. [Abstract]

6. Szpalski M, Gunzburg R. Lumbar spinal stenosis: clinical features and new trends in surgical treatment. Geriatr Times 2004;5:11-3.

7. Kauffman C, Garfin SR. Spinal stenosis: pathophysiology and symptom complex update 1999. Semin Spine Surg 1999:11:209-14.

8. Katz JN. Lumbar disc disorders and low-back pain: socioeconomic factors and consequences. J Bone Joint Surg Am 2006;2:21. [Abstract]

9. Taylor VM, Deyo RA, Cherkin DC, Kreuter W. Low back pain hospitalization: recent US trends and regional variations. Spine 1994;19:1207-11.

10. Atlas SJ, Delitto A. Spinal stenosis: surgical versus nonsuraical treatment. Clin Orthop Relat Res 2006;443:198-207. [Abstract]

11. Weiner DK. Office management of chronic pain in the elderly. Am J Med 2007;120:306-15

12. Inufusa A, An HS, Lim TH, Hasegawa T, Haughton VM, Nowicki BH. Anatomic changes of the spinal canal and intervertebral foramen associated with flexion-extension movement. Spine 1996;21:2412-20. [Abstract]

13. Takahashi K, Kagechika K, Takino T, Matsui T, Shima I. Changes in epidural pressure during walking in patients with lumbar spinal stenosis. Spine 1995;20:2746-9. [Abstract]

14. Kobayashi S, Baba H, Uchida K, Kokubu Y Yayama T, Takeno K, et al. Blood circulation of cauda equina and nerve root [Japanese]. Clin Calcium 2005;15:63-72

15. Siebert E, Prüss H, Klingebiel R, Failli V, Einhäupl KM, Schwab JM. Lumbar spinal stenosis: syndrome, diaqnostics and treatment. Nat Rev Neurol 2009:5:392-403. [Abstract] / [Full Text] / [PDF]

16. Kent DL, Haynor DR, Larson EB, Deyo RA. Diagnosis of lumbar spinal stenosis in adults: a meta-analysis of the accuracy of CT, MR, and mvelography. AJR Am J Roentgenol 1992;158:1135-44. [Abstract] / [PDF]

17. Boden SD, Davis DO, Dina TS, Patronas NJ, Wiesel SW. Abnormal magnetic-resonance scans of the lumbar spine in asymptomatic subjects. A prospective investigation. J Bone Joint Surg Am 1990;72:403-8. [Abstract] / [PDF]

18. Amundsen, $\mathrm{T}$, Weber $\mathrm{H}$, Lilleas $\mathrm{F}$, Nordal $\mathrm{HJ}$, Abdelnoor $\mathrm{M}$, Magnaes B. Lumbar spinal stenosis. Clinical and radiologic features. Spine 1995;20:1178-86. [Abstract] 
19. Moon ES, Kim HS, Park JO, Shin DE, Ha JW, Shim DJ, Kwak YH, Lee KI. Comparison of the predictive value of myelography, computed tomography and MRI on the treadmill test in lumbar spinal stenosis, Yonsei Med J 2005:46:806-11. [Abstract] / [Full Text] / [PDF]

20. Barz T, Melloh M, Staub L, Roeder C, Lange J, Smiszek FG, et al. The diagnostic value of a treadmill test in predicting lumbar spinal stenosis. Eur Spine J 2008:17:686-90. [Abstract] / [Full Text] / [PDF]

21. Sirvanci M, Bhatia M, Ganiyusufoglu KA, Duran C, Tezer M, Ozturk $C$, et al. Degenerative lumbar spinal stenosis: correlation with Oswestry Disability Index and MR imaqing. Eur Spine $J$ 2008;17:679-85. [Abstract] / [Full Text] / [PDF]

22. Ogikubo $\mathrm{O}$, Forsberg $\mathrm{L}$, Hansson $\mathrm{T}$. The relationship between the cross-sectional area of the cauda equina and the preoperative symptoms in central lumbar spinal stenosis. Spine 2007:32:1423-9. [Abstract]

23. Elliot FA. Tender muscles in sciatica: electromyographic studies. Lancet 1944;47-9. [Full Text]

24. White JC. The ubiquity of contraction enhanced H-reflexes: normative data and use in the diagnosis of radiculopathies. Electroencephalogr Clin Neurophysiol 1991;81:433-42. [Abstract]

25. Eisen A, Schomer D, Melmed C. The application of F-wave measurements in the differentiation of proximal and distal upper limb entrapments. Neurology 1977;27:662-8. [Abstract] / [Full Text]

26. Fisher MA. $H$ reflexes and $F$ waves: Physioloqv and clinical indications. Muscle Nerve 1992;15:1223-33. [Abstract] / [PDF]

27. Fisher MA, Shidve AJ, Teixera C, Grainer LS. The F response: A clinically useful physiological parameter for the evaluation of radicular injury. Electromyogr Clin Neurophysiol 1979;19:65-75.

28. Aminoff MJ: Electromyography in Clinical Practice, 3rd ed. New York, Churchill Livingstone, 1998;4:99-114.

29. Dumitru D. Electrodiagnostic Medicine. Philadelphia: Hanley and Belfus, Inc., 1995. p. 557-76.

30. Tang LM, Schwartz MS, Swash M. Postural effects on F wave parameters in lumbosacral root compression and canal stenosis. Brain 1988;111:207-13. [Abstract] / [PDF]

31. London SF, England JD. Dynamic $F$ waves in neurogenic claudication. Muscle Nerve 1991:14:457-61. [Abstract] / [Full Text]

32. Adamova B, Vohanka S, Dusek L. Dynamic electrophysiological examination in patients with lumbar spinal stenosis: is it useful in clinical practice? Eur Spine J 2005:14:269-76. [Abstract] [Full Text] / [PDF]

33. Adamova B, Vohanka S, Dusek L. Differential diagnostics in patients with mild lumbar spinal stenosis: the contributions and limits of various tests. Eur Spine J 2003;12:190-6. [Abstract] / [PDF]

34. Wallbom AS, Geisser ME, Haig AJ, Koch J, Guido C. Alterations of F wave parameters after exercise in symptomatic lumbar spinal stenosis. Am J Phys Med Rehabil 2008;87:270-4. [Abstract]

35. Tans RJ, Vredeveld JW. Somatosensory evoked potentials (cutaneous nerve stimulation) and electromyography in lumbosacral radiculopathy. Clin Neurol Neurosurg 1992;94:15-7. [Abstract]

36. Oh SJ. Clinical Electromyography: Nerve Conduction Studies. Baltimore: University Park Press, 1984. p. 47-64

37. Wilbourn AJ. The value and limitations of electromyographic examination in the diagnosis of lumbosacral radiculopathy. In: Hardy RW (Ed). Lumbar Disc Disease. New York: Raven Press, 1982. p. 65-109.

38. Jankus WR, Robinson LR, Little JW. Normal limits of side to-side H-reflex amplitude variability. Arch Phys Med Rehabil 1994;75:3-7. [Abstract]

39. Scarberry $S$, Al-Hakim $M$, Katirii B. H-reflex amplitude in the healthy elderly. Muscle Nerve 1994;17:1350-62.

40. Kuruoglu R, Oh SJ, Thompson B. Clinical and electromyographic correlations of lumbosacral radiculopathy. Muscle Nerve 1994:17:250-1.

41. Plastaras CT. Electrodiagnostic challenges in the evaluation of lumbar spinal stenosis. Phys Med Rehabil Clin N Am 2003;14:57-69. [Abstract] / [Full Text] / [PDF]

42. Nardin $R$, Patel $M$, Gudas $T$, Rutkove SB, Raynor EM. Electromyography and magnetic resonance imaging in the evaluation of radiculopathy. Muscle Nerve 1999:22:151-5. [Abstract] / [Full Text] / [PDF]

43. Grana E, Kraft G. Lumbosacral radiculopathies, distribution of electromyographic findings. Muscle Nerve 1992;15:1204.

44. Wilbourn AJ Aminoff MJ. AAEM minimonograph 32: the electrodiagnostic examination in patients with radiculopathies. American Association of Electrodiagnostic Medicine. Muscle Nerve 1998;21:1612-31. [Abstract] / [Full Text] / [PDF]

45. Petropoulos BP. Lumbar spinal stenosis syndrome. Clin Orthop Relat Res 1989:246:70-80. [Abstract]

46. Chu-Andrews J, Johnson R. Electrodiagnosis: an anatomical and clinical approach. Philadelphia: J. B. Lippincott, 1986. p. 253-4.
47. Buchtal F, Gold C, Rosenfalck P. Multielectrode study of the territory of a motor unit. Acta Physiol Scand 1957;39:83-104.

48. See $\mathrm{DH}$, Kraft GH. Electromyography in paraspinal muscles following surgery for root compression. Arch Phys Med Rehabil 1975;56:80-3. [Abstract]

49. Dillingham T, Lauder T, Andary M, Kumar S, Pezzin LE, Stephens $\mathrm{RT}$, et al. Identifying lumbosacral radiculopathies: an optimal electromvographic screen. Am J Phys Med Rehabil 2000;79:496-503. [Abstract]

50. Dumitru D, Diaz C, King J. Prevalence of denervation in paraspinal and foot intrinsic musculature. Am J Phys Med Rehabil 2001;80:482-90. [Abstract]

51. Kraft GH. Fibrillation potential amplitude and muscle atrophy following peripheral nerve injury. Muscle Nerve 1990;13:814-21. [Abstract] / [PDF]

52. Eisen $A$, Hoirch $M$. The electrodiaqnostic evaluation of spinal root lesions. Spine 1983;8:98-105. [Abstract]

53. Keim HA, Hajdu M, Gonzalez EG, Brand L, Balasubramanian E. Somatosensory evoked potentials as an aid in the diagnosis and intraoperative management of spinal stenosis. Spine 1985:10:338-44. [Abstract]

54. Kraft GH, Aminoff MJ, Baran EM, Litchy WJ, Stolov WC. Somatosensory evoked potentials: clinical uses. Muscel Nerve 1998;21:252-8. [Abstract] / [PDF]

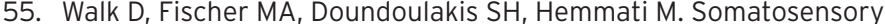
evoked potentials in the evaluation of lumbosacral radiculopathy. Neurology 1992;42:1197-202. [Abstract] / [Full Text]

56. Herron LD, Trippi AC, Gonyeau M. Intraoperative use of dermatomal somatosensory-evoked potentials in lumbar stenosis surgery. Spine 1987;12:379-83. [Abstract]

57. Spielholz NI, Benjamin MV, Engler GL, Ransohoff J. Somatosensory evoked potentials during decompression and stabilization of the spine. Spine 1979;4:500-5. [Abstract]

58. Brown RH, Nash CL, Berilla JA, Amaddio MD. Cortical evoked potential monitoring a system for intraoperative monitoring of spinal cord function. Spine 1984;9:256-61. [Abstract]

59. Kondo M, Matsudo $H$, Kureya S, Shimazu A. Electrophysiological studies of intermittent claudication in lumbar stenosis. Spine 1989;14:862-6. [Abstract]

60. Dvonch V, Scarff T, Bunch W, Smith D, Boscardin J, Lebarge H, et al. Dermatomal somatosensory evoked potentials: their use in lumbar radiculopathy. Spine 1984:9:291-3. [Abstract]

61. Storm SA, Kraft GH. The clinical use of dermatomal somatosensory evoked potentials in lumbosacral spinal stenosis. Phys Med Rehabil Clin N Am 2004;15:107-15. [Full Text] / [PDF]

62. Snowden ML, Haselkorn JK, Kraft GH, Bronstein AD, Bigos SJ, Slimp JC, et al. Dermatomal somatosensory evoked potentials in the diagnosis of lumbosacral spinal stenosis: Comparison with imaging studies. Muscle Nerve 2004;15:1036-44. [Abstract]

63. Jensen MC, Brandt-Zawadzki MN, Obuchowski N, Modic MT, Malkasian D, Ross JS. Magnetic resonance imaging of the lumbar spine in people without back pain. N Eng J Med 1994;331:69-73.

64. Tokuhashi $Y$, Satoh K, Funami S. A quantitative evaluation of sensory dysfunction in lumbosacral radiculopathy. Spine 1991;16:1321-8. [Abstract]

65. Haig AJ, Talley C, Grobler LJ, LeBreck DB. Paraspinal mapping: Quantified needle electromyoaraphy in lumbar radiculopathy. Muscle Nerve 2004;16:477-84. [Abstract]

66. Yagci I, Gunduz OH, Ekinci G Diracoglu D Us O, Akyuz G. The utility of lumbar paraspinal mapping in the diagnosis of lumbar spinal stenosis. Am J Phys Med Rehabil 2009; Aug 5 Epub ahead of print.

67. Tomasella M, Crielaard JM, Wang FC. How I explore...lumbar paraspinal muscle electromyography in the assessment of radiculopathy (Article in French). Rev Med Liege 2001;56:716-22. [Abstract]

68. Leionnen V, Maata S, Taimela S, Herno A, Kankaanpaa M, Partanen $J$, et al. Paraspinal muscle denervation, paradoxically good lumbar endurance, and an abnormal flexion-extension cycle in lumbar spinal stenosis. Spine 2003;28:324-31. [Abstract]

69. Haig AJ, Tong HC, Yamakawa KS, Quint DJ, Hoff JT, Chiodo A et al. The sensitivity and specificity of electrodiagnostic testing for the clinical syndrome of lumbar spinal stenosis. Spine 2005;30:266776. [Abstract]

70. Tong HC, Young IA, Koch J, Haig AJ, Yamakawa KS, Wallbom A. Paraspinal electromyography that compares concentric with monopolar needles: a blinded study. Am J Phys Med Rehabil 2003;82:917-24. [Abstract]

71. Haig AJ, Yamakawa K, Hudson DM. Paraspinal electromyography in higher lumbar and thoracic lesions. Am J Phys Med Rehab 2000;79:336-42. [Abstract]

72. Kraft GH. Dermatomal somatosensory-evoked potentials in the evaluation of lumbosacral spinal stenosis. Phys Med Rehabil Clin N Am 2003;14:71-5. [Abstract] 